\title{
The Nexus between Nigerian Government Spending and Domestic Output in the Presence of Long-Term Crude Oil Price Shock: A Conditional Unrestricted Equilibrium Correction Model Approach
}

\author{
Lawal Omoniyi Ganiyu1, Alabi Nurudeen Olawale1, Ige Sikiru Ajibade², \\ Ibraheem Rahmat Abisola ${ }^{1}$ \\ ${ }^{1}$ Department of Statistics, Yaba College of Technology, Lagos, Nigeria \\ ${ }^{2}$ Department of Mathematics, Yaba College of Technology, Lagos, Nigeria \\ Email: nurudene.alabi@gmail.com
}

Received 6 January 2016; accepted 11 June 2016; published 14 June 2016

Copyright (C) 2016 by authors and Scientific Research Publishing Inc.

This work is licensed under the Creative Commons Attribution International License (CC BY). http://creativecommons.org/licenses/by/4.0/

(c) (i) Open Access

\begin{abstract}
This paper is an empirical analysis of provisional unrestricted level relationship between Nigerian domestic output measured by Gross Domestic Product (GDP) and government spending proxied by capital and recurrent expenditures in the presence of static regressors such as crude oil prices and federal government retained revenues. We estimate an ARDL $(1,0,1)$ using a single-equation approach. Results show that government expenditures have negative but statistically insignificant effects on domestic output in the long-run. Similarly, negative short run effects are established amongst the variables. However, recurrent expenditure is statistically significant in the short-run. Whilst federal government retained revenue has a positive and significant effect, crude oil price exhibited negative relationships with domestic output both at level and in the short-run dynamics. Also a high speed of adjustment implies that Nigerian Gross Domestic Product is extremely sensitive to shocks on the government spending in the long-run. An upward trend forecast between 2014 and 2020 is an indication of the continued positive impact and the government retained revenue will exert on the domestic output in the long-run.
\end{abstract}

\section{Keywords}

Level Relationship, Domestic Output, Government Spending, Single-Equation Approach 


\section{Introduction}

The discovery of crude oil (oil hereon) in commercial quantities since 1960 has changed the economic structure of Nigeria from an agriculture-based to oil dependent one. This development by no small measure has consistently resulted in over dependence on oil since 1970, a period characterized by oil boom when oil revenue accounted for more than 90 percent of the export income and over 80 percent of government revenues. It is without doubt revenues from oil accounted for about 82 percent of total government revenue during the oil boom era. Although oil revenue dropped to 64 percent in the second half of 1980s, as a result of rapid decline in world oil price, its share of total government revenue still remained substantial (Figure 1). According to Nigeria National Petroleum Corporation (NNPC), Nigeria presently has a fairly large deposit of oil with about 28.2 billion barrels of reserve ${ }^{1}$. Consequently, the country has remained a key member of the Organization of Petroleum Exporting Countries (OPEC) producing on the average, 2.3 million barrels of oil per day (bpd, hereon) since 1996. Notwithstanding the global dominance in terms of oil production and consistent yearly increases in gross domestic product per capital, Nigeria's oil wealth has not been completely utilized to elevate the common masses from economic impoverishment to prosperity ${ }^{2}$. The majority of the masses are poor living below $\$ 100$ per year. Furthermore, the country has been unable to transform its rich resources into economic development to reflect the country's level of endowments.

Oil has significantly influenced the size of both the federal and state governments' finances over the years. Since the early 1970s, over half of annual government retained revenues (Figure 1) come directly from the oil sector (sometimes as much as 85 percent). In addition to large oil revenues, government retained revenues are extremely volatile by changing rigorously in size on yearly basis resulting in significant instability in both the size and the funding of government agendas. For instance, between 1996 and 1999, government spending rose from 8.4 percent to 20.3 percent of domestic output; by 2010, it dropped back to a single digit figure of 7.7 percent of the domestic output before rising to 14.7 percent in 2012. It has maintained a southward trend since then. The negative trend in the government spending was reflective of the pattern exhibited by the total revenue as percentage of the domestic output over a three-year period from 2012 to 2014. Between 2012 to 2014 , total government revenue dropped to 14.3 percent, 11 percent, 9.9 percent of the domestic output respectively. States and local governments spending (both recurrent and capital expenditures) on administration, economic services,

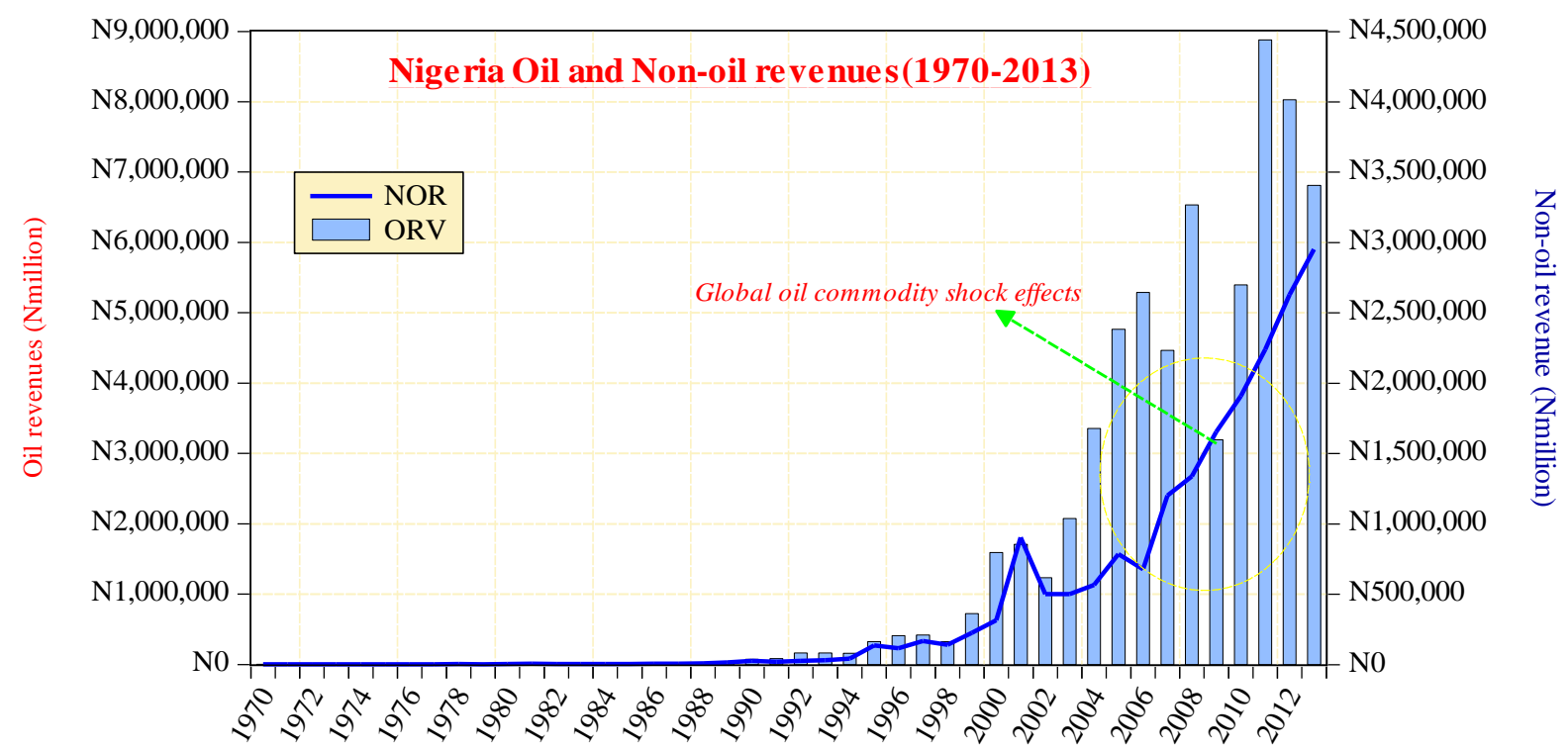

Figure 1. Nigeria oil and non-oil revenues (1970-2013).

${ }^{1}$ Nigeria was ranked $8^{\text {th }}$ (3.1 percent) amongst OPEC countries and $2^{\text {nd }}$ behind Libya in Africa in terms of contribution to the 81 percent of OPEC share of world oil reserves in 2014. The current production level of about 1.8 million bpd implies that Nigeria will deplete the oil reserve in about 43 years (2059).

${ }^{2}$ Nigeria like many other nations depending on mineral resources experiences economic instability, high corruption rates, unstable democratic system, high risk of civil war. Economic instability led to significant macroeconomic shocks and unstable government revenues (Figure 1) which affect the living standard of the masses. 
social community services and transfers as percentage of domestic output dropped consistently from 11.65 percent in 1981 to 4.47 percent in 2014. In fact, by the end of 2014, most state governments were struggling with recurrent expenditure on general administration, internal security, education, health, agriculture, construction, transportation, public debt servicing and there were abandoned capital projects. This was partly due to a major shock on oil price ${ }^{3}$ (Figure 3) in June 2014, which resulted in the significant drop in the size of excess crude account, a major source of federal and states governments finances from the federal allocation accounts. The sharing formula of excess revenue from oil (or the so called Sovereign Wealth Fund, SWF) was revised with states getting less than 20 percent from the 40 per cent sharing formula prior to the oil $\mathrm{crash}^{4}$. States which have little or no other sources of generating income especially internally generated revenues (IGR) were worse affected. The continued inability of these states governments to manage funds judiciously, and limit corruption led to reactions from several unions across the country.

Furthermore, financial system stability and some key macroeconomic indicators especially the foreign reserve, exchange rate ${ }^{5}$ and the stock market All Share Index were negatively affected. Historically, both the federal and states governments are known to have failed to implement prudent fiscal policy during the 1970's and 1980's, periods when oil price fluctuated sharply. Additionally, after the civil war of 1967 to 1970, significant amount of oil revenue were transferred from federal to the state and local governments due to decentralization of Nigerian government, which further complicated the efficient revenue administration. Figure 2 and Figure 3 illustrate the interactions between government spending (total recurrent and capital expenditures), oil prices and Nigeria domestic output between 1970 and 2013.

Figure 2 reveals that the capital expenditure and recurrent expenditure exhibit upward trend from late 1980's with recurrent expenditure rising faster than the capital expenditure at most times. Between 1995 and 1998, capital expenditure was higher than recurrent expenditure. After the country returned to democratic system of government in 1999, recurrent expenditure has been higher than the capital expenditure. It was also revealed that a

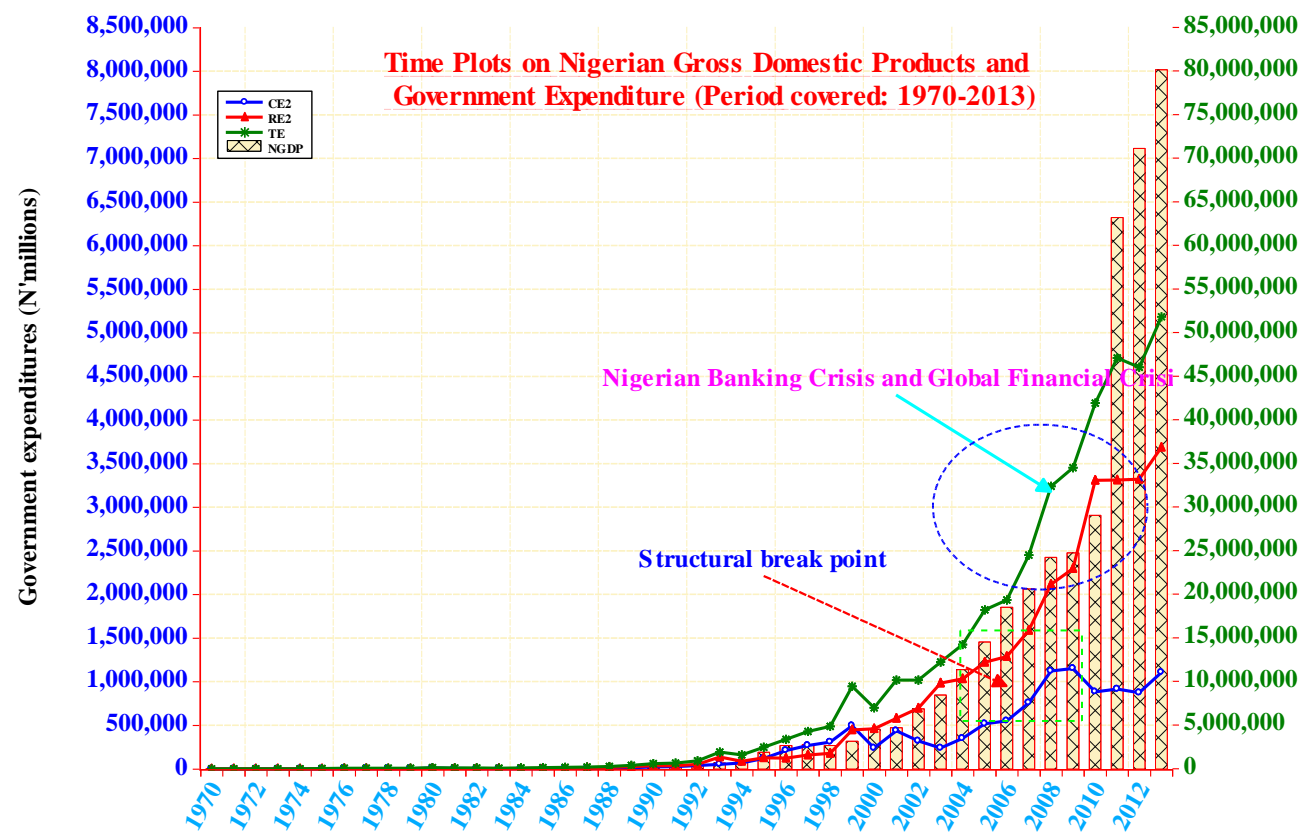

Figure 2. Time plots on Nigeria gross domestic products and government expenditure (1970-2013).

\footnotetext{
${ }^{3}$ Unlike the 2008 oil price crash which was as a result of speculative trading in oil futures, the recent crash since June 2014 has been associated with increase in unconventional oil, global supply outstripping global demand due to low demand from China, policy shift by OPEC, crisis in the Middle East and major oil producers, US lifting of ban on oil export [1].

${ }^{4}$ States governments were allocated $\$ 966.6$ billion, $\$ 816.3$ billion, $\$ 859.4$ billion and N282.8 in 2011, 2012, 2013 and 2014 respectively. The 67 percent drop in 2014 reflects significant impact of the crash in global oil prices recorded in June. In 2012, 2013, 2014 the SWF as percentage of GDP was 11 percent, 3.8 percent and 3.6 percent respectively.

${ }^{5}$ Shocks on macroeconomic indicators create problems such as monetary and fiscal policy inefficiencies, local currency devaluation, and lower credit to drive investment in the private sector and more importantly high FDI outflows or capital flight. According to a model postulated by [1], a supply driven decline in oil price was associated with depreciation in the value of the Naira to the US dollars.
} 


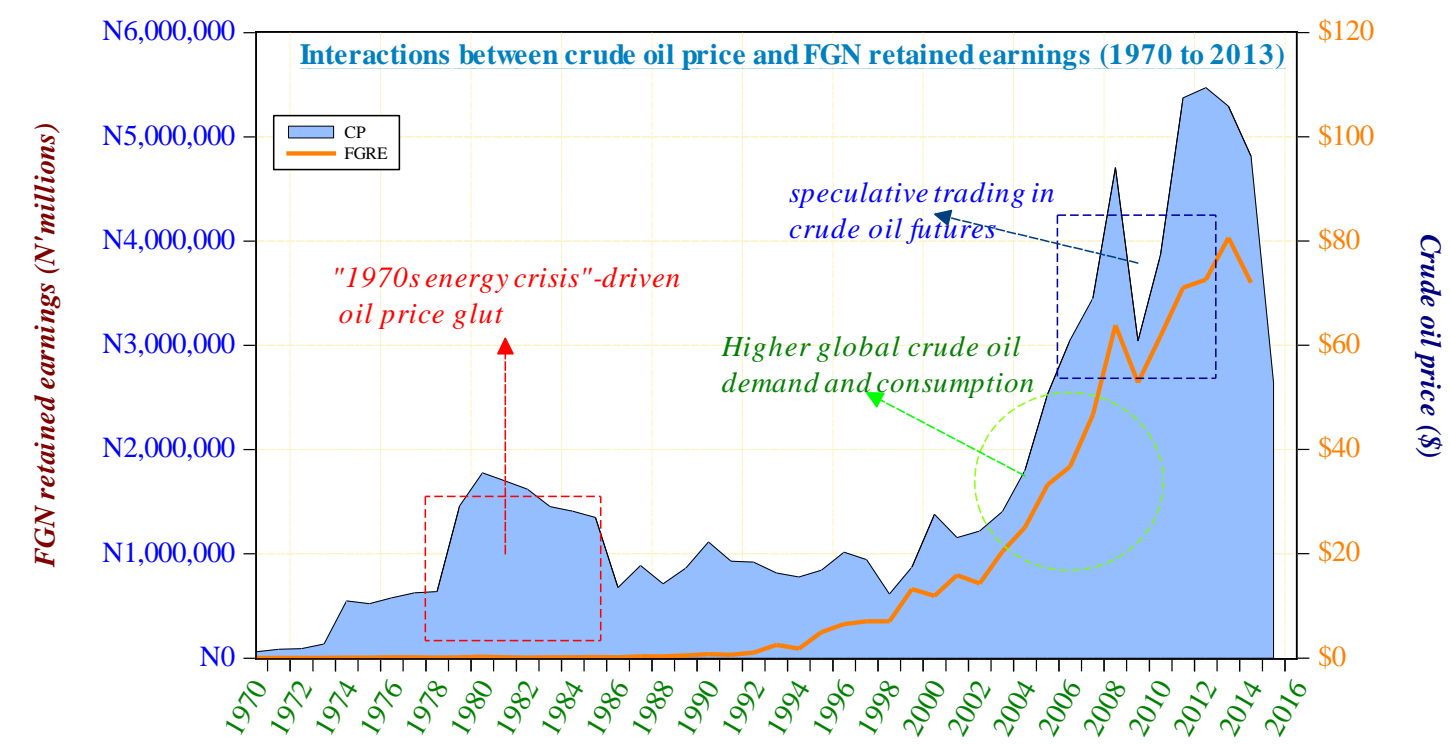

Figure 3. Interactions between crude oil price and FGN retained earnings (1970-2013).

constant relationship existed between domestic output and total expenditure from 1970 till 1992.

Similarly, Figure 3 shows the effects of the series of energy crisis in the 1970s in which the major industrial economies such as United States, Great Britain, Germany, Japan and France were heavily affected and faced substantial oil shortages, which caused oil price hike. Furthermore, there had been drastic changes in price of oil over the last few decades in Nigeria. Changes which usually force government to adjust expenditures accordingly. This creates a dilemma especially in capital expenditures because they are entirely financed by oil revenues.

Obviously, government spending increased when oil prices and public revenues increased particularly in the 1970s and early 1980s as revenues from export were diverted to the domestic economy. Between 1980 and 2008 , oil oversupply occurred which raised world demand by more than 41 per cent, from 60 million bpd to over 85 million bpd. This resulted in a sharp rise in oil prices especially in the early 2000's until 2008. Consequently, government retained revenue rose in relation to the rising oil prices. By 2008, a significant oil commodity shock, which emanated from the famous 2008 global financial crisis led to substantial crash in oil prices and consequently sharp drop in government retained earnings. By mid-2014, another major shock was recorded not as a consequence of increasing world demand but oversupply from OPEC countries ${ }^{6}$, which removed production ceiling of 30 million bpd at the end of 2015. Hence, the two major fundamental questions this research work attempts to answer are:

$\checkmark$ How significant are the impacts of government spending and dwindling oil prices on the domestic output of Nigeria?

$\checkmark$ How can Nigeria forestall a total economic breakdown as a result of the recent persistent dip in oil prices?

Many important studies have attempted this question of how oil prices influenced Nigerian domestic output and political life as discussed below. However, one of the ways the current research work attempts to answer the questions above as a contribution to the existing rich literature on the topic is by studying scientifically, relationships between government spending (which oil prices influence directly) and the domestic output since the oil boom era.

\section{Related Work}

According to studies conducted by [3], there exists an unstable negative relationship between domestic output

${ }^{6}$ OPEC increased production in response to the inexpensive US shale oil boom leading to price war and truce reached in Libya. Shale Oil according to [2] report (2013) is a low cost and important unconventional resource in US. Its production grown by more than 26 percent from 111,000 bpd in 2004 to more than 553,000 bpd in 2011. US Energy Information Administration (EIA) emphasized that shale oil production will continue to rise which has further led to OPEC insisting on removing ceiling on daily production of oil even if the oil price drops below the $\$ 20$ per barrel mark. 
and crude oil prices. This weak reaction was partly associated with smaller energy concentration [4]. This is in line with theory that oil price shock is costly for economy which is dependent on natural resources. An import oriented market like Nigeria does not experience significant growth in domestic output during oil price rise largely due to subsidy primarily funded by revenues from oil sales and poor level of power infrastructure. The latter has adverse effect on firms relying heavily on oil for their processes. These firms expend a significant portion of their proceeds on power supply.

Conversely, [5] [6] found positive relationship between oil prices and growth of domestic output in Nigeria. Their work emphasized that growth in domestic output does not always translate into real economic growth in Nigeria. This fact has been reflected in the Nigerian's government retained revenue late in the 1990s and early 2000s when oil prices declined and rose steadily respectively (Figure 3). Oil plays a significant role in the Nigerian economy as the largest contributor in terms of total government revenue but also as the overall contributor in the country's exports composition. In South Africa, Ghana and Tunisia, it was established that a negative relationship existed between oil price and growth in domestic output [7]-[9] respectively. In the United States, oil price increase was associated with drop in domestic output during the 1970s and 1980s energy crisis experienced in most industrialized economies.

[10] using the Hodrick Prescott (HP) procedure studied the relationships between fiscal spending indicators such as capital, recurrent and total expenditures and domestic output concluded that only total and capital expenditures had negative correlations with domestic output growth. [11] employed error correction model and two band recursive least squares to measure the effectiveness and stability of government fiscal policy on domestic output using a 40-year data from 1970 to 2010. He concluded that fiscal deficit which is a function of government total expenditure and government retained earnings have a strong significant positive relationship with domestic output. Also, their work revealed that fiscal policy tends to have more significant impact on Nigeria domestic output both in the long-run and short-run.

Another study by [12] employed impulse response function (IRF) and variance decomposition to measure the responsiveness of Nigeria domestic output growth to shocks on monetary and fiscal policies revealed that shocks on government revenue rather than government expenditure produced more positive response from gross domestic product growth in the long run. Similarly, [13] studied the effectiveness of monetary and fiscal policies on the economic activity in Nigeria by employing cointegration and error correction modeling of two-equation system. Their primary objective was to determine which of the policies has greater, more predictable and faster effect on domestic output growth. They concluded that monetary policy is more effective than fiscal policy in measuring domestic output stabilization. Furthermore, fiscal policy has negative effect on domestic output. [14] concluded that there exists a long-run equilibrium in the growth of real GDP as a function of monetary and fiscal policies in the period 1970-2003. The empirical results also showed that fiscal policy appears to support the policy ineffectiveness proposition. By establishing a unidirectional causal relationship from government expenditure to domestic output [15] concluded that government spending accounted for some level of economic growth in Nigeria from the oil boom era 1970 to 2006.

\section{Model Setup, Estimation and Results}

This research work employed one of the long-standing cointegration methods, Autoregressive Distributed Lag Modeling (Bounds Testing Procedure) as proposed by [16] [17] to establish a conditional unrestricted level long-run relationship between Nigeria domestic output and government fiscal policy. The reason for its preference over residual based, maximum likelihood based and the single based equation of [18] and [19], Fully Modified OLS and Dynamic OLS methods respectively was that apriori knowledge of the underlying properties of the data generating process (d.g.p, hereon) of the time series was not necessary ${ }^{7}$. Furthermore, this method possesses relatively better performance when the sample size $T$ is small and it is applicable to a mixture of stationary and non-stationary time series [1]. In order words, regardless of the d.g.p of our selected time series, bounds testing procedure establishes a single cointegrated equation of long-run relationships via ordinary least squares (OLS). In addition, it allows for inclusion of different lags of the response variable and the explanatory variables using the simple model selection methods which will be discussed later in this paper. The current study involves a 44-yearly data/observations of Nigeria Gross Domestic Product (ngdp), Capital Expenditure (ce),

\footnotetext{
${ }^{7}$ These traditional methods of cointegration required that all variables including the response and explanatory variables be non-stationary of order one i.e. must be strictly $\mathrm{I}(1)$.
} 
Recurrent Expenditure (re), crude oil price (cp), federal government retained earnings/revenues (fgre) between 1970 and 2013. The source of data on the five variables is the Central Bank of Nigeria database. The ARDL postulated in this paper is a least square regression equation with varied lags of the variables denoted as ARDL $\left(p, p_{1}, p_{2}\right)$ whereby $p$ is the number of lags of the Nigeria Gross Domestic Product (ngdp), $p_{1}$ and $p_{2}$ are the number of lags of Capital Expenditure (ce) and Recurrent Expenditure (re) respectively. We assumed that the response and explanatory variables can be approximated by the natural log-linear $\operatorname{VAR}(p)$ model to sustain the normality assumption particularly in the error term in the model. The $\operatorname{VAR}(p)$ of ngdp equations and associated assumptions $^{8}$ are given in Equations (1) and (2) below:

$$
\begin{gathered}
y_{t}=c_{0}+c_{1} t_{t}+c_{2} D 2009_{t}+\sum_{i=1}^{p} \lambda_{i} y_{t-i}+\sum_{j=1}^{k+2} \sum_{i=o}^{p_{j}} z_{j, t-i}^{\prime} \beta_{j, i}+\epsilon_{t} \\
\Delta y_{t}=-\sum_{i=1}^{p} \lambda_{i}^{*} \Delta y_{t-1}+\tau^{*} \Delta t_{t}+\psi^{*} \Delta D 2009_{t}+\sum_{j=1}^{k+2} \sum_{i=o}^{p_{j-1}} \Delta z_{j, t-i}^{\prime} \beta_{j, i}^{*}-\hat{\phi} E C_{t-1}+\epsilon_{t}
\end{gathered}
$$

where one or more of the explanatory variables in the vector $\mathbf{z}_{j}^{9}$ are fixed or static i.e. have no lagged terms in the model $\left(p_{j}=0\right) . \Delta$ is the first difference operator, $\boldsymbol{y}_{t}$ is the Nigeria Gross Domestic Product (ngdp) at level, $c_{0}$, $c_{1}$ and $c_{2}$ are deterministic intercept, trend coefficients and dummy variable respectively. We observed progressively rising trends in domestic output, government expenditures, crude oil price and federal government retained earnings/revenues suggesting that a linear trend ought to be included in the domestic output Equation (1) (Figure 2 \& Figure 3). This in addition to the presence of the intercept made the model conditional unrestricted. An initial application of non-stationarity tests to the five variables indicated at least one unit root. Furthermore, a "one-off" dummy variable D2009 was introduced to capture an inherent structural break that occur in 2009 due to slowed global output growth.

$$
D 2009_{t}= \begin{cases}1, & \text { over the period } 2009 \text { to } 2013 \\ 0, & \text { elsewhere }\end{cases}
$$

The introduction of D2009 in Equation (1) does not affect the asymptotic properties of the F-statistic in the bounds test procedure since the proportion of 1's reduces with increasing sample size $T$. Determination of the number of lags in the level Equation (1) was done using the simple model selection methods such as Akaike Information Criterion (AIC), Schwarz Information Criterion (SIC), and the Hannan-Quinn Information Criterion (HQIC) $^{10}$. Figure 4 illustrates graphically, the top twenty models out of a total of 100, 294 and 100 models considered based on the model selection procedures respectively. We favored the HQIC method because of its similarity with SIC ${ }^{11}$ method otherwise the later will be preferred. Summarily, the AIC, SIC and HQIC selected an ARDL $(3,0,2)$, ARDL $(1,0,1)$ and ARDL $(1,0,1)$ models respectively. At each stage of model selection when the explanatory variables in the $(k+2) \times 1$ vector $\mathbf{Z}_{\mathrm{t}}$ enters the model, we ensured that model stability and the residual serial non-autocorrelation using the VAR stability condition test and Lagrange Multiplier (LM) statistics were satisfied.

The Equation (1) is a dynamic relationship between Nigeria Gross Domestic Product (ngdp), Capital Expenditure (ce) and Recurrent Expenditure (re), Crude Oil Price (cp), Federal Government Retained Earnings/Revenues (fgre). Hence, the long-run coefficients based on the long run response of GDP to a change in government expenditures was estimated as

\footnotetext{
${ }^{8}$ Model Assumptions: 1) The scalar disturbance term, $\epsilon_{t}$, in Equation (1) is i.i.d. (0, $\left.\sigma_{\epsilon}^{2}\right)$; 2) The $k$-dimensional vector, $\epsilon_{t}$, has a general linear multivariate stationary process; 3) $\epsilon_{t}$ are uncorrelated for all leads and lags such that $\mathbf{z}_{t}$ is strictly exogenous with respect to $\epsilon_{t}$; 4) The I(1) regressors, $\boldsymbol{z}_{t}$, are not cointegrated among themselves; 5) The inverse root of the autoregressive characteristic polynomial is strictly less than one, so that the model is dynamically stable, and a long-run relationship between $\boldsymbol{y}_{t}$ and $\boldsymbol{z}_{t}$ exists.

${ }^{9} \mathbf{Z}_{\mathrm{j}}$ is a $(k+2) \times 1$ vector of explanatory variables which includes the main independent variables such as Capital Expenditure (ce) and Recurrent Expenditure (re), the static independent variables such as the Federal Government Retained Earnings/Revenues(fgre), crude oil price (cp).

${ }^{10}$ The proper choice of the lag order $p$ was such that it was neither too small nor too large [20]. If small, the variables excluded from the model will enter the shocks $\boldsymbol{\epsilon}_{t}$, thereby leading to residual serial correlation problem. Contrarily, if the $p$ is large, this will result in over-parameterization of the model in Equation (1) [20]. The maximum lag $=4$ for each of the models.

${ }^{11}$ The SIC also known as the Bayes Criterion (BIC) is the most consistent model selection method amongst the three. It also deals with the issue of over specification of the model usually associated with the AIC method.
} 
Akaike Information Criteria (top 20 models)

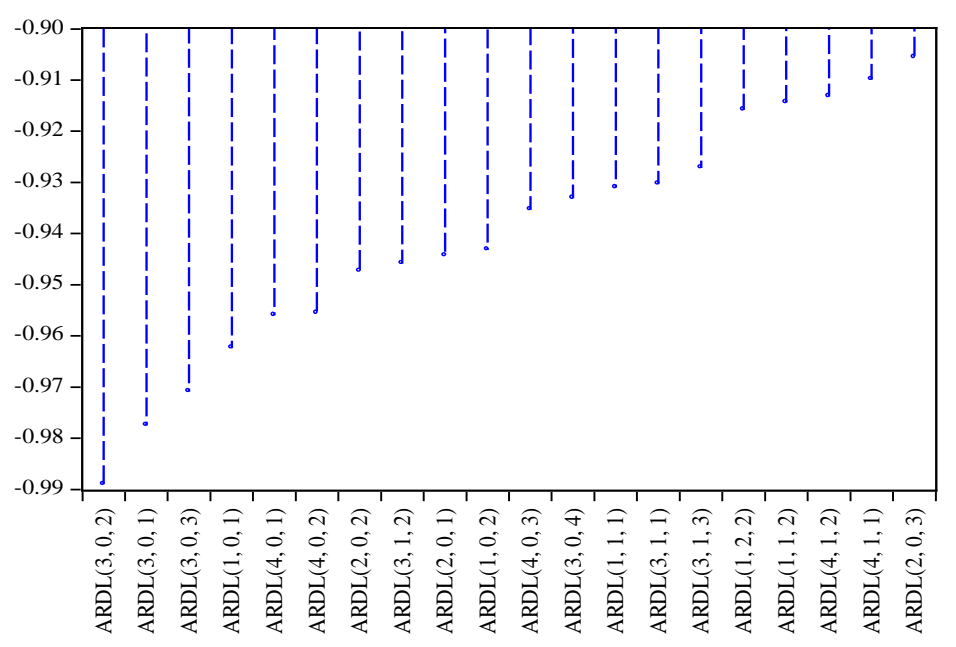

Hannan-Quinn Criteria (top 20 models)

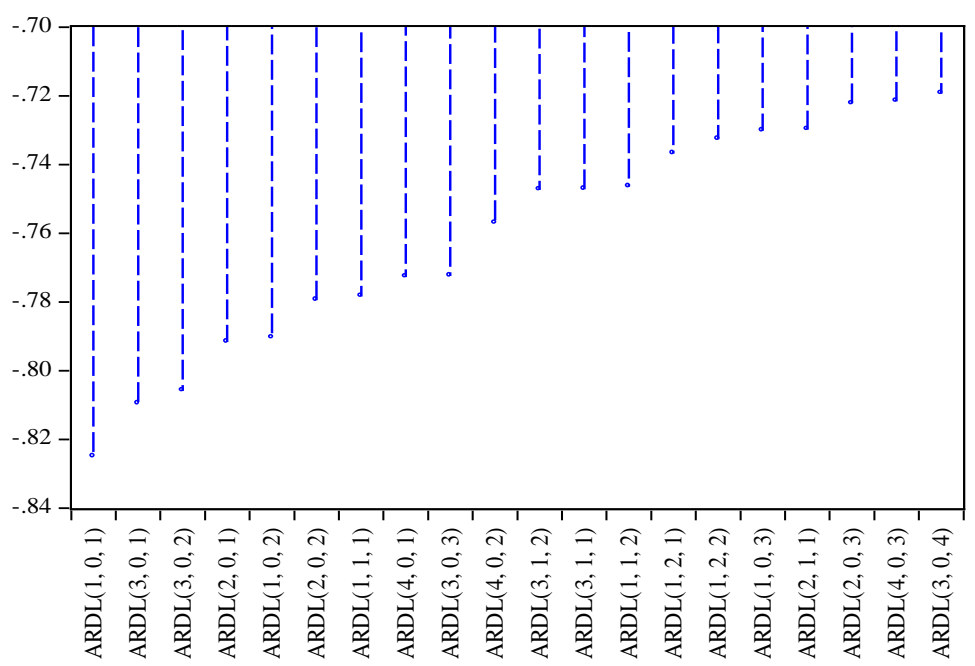

Schwarz Criteria (top 20 models)

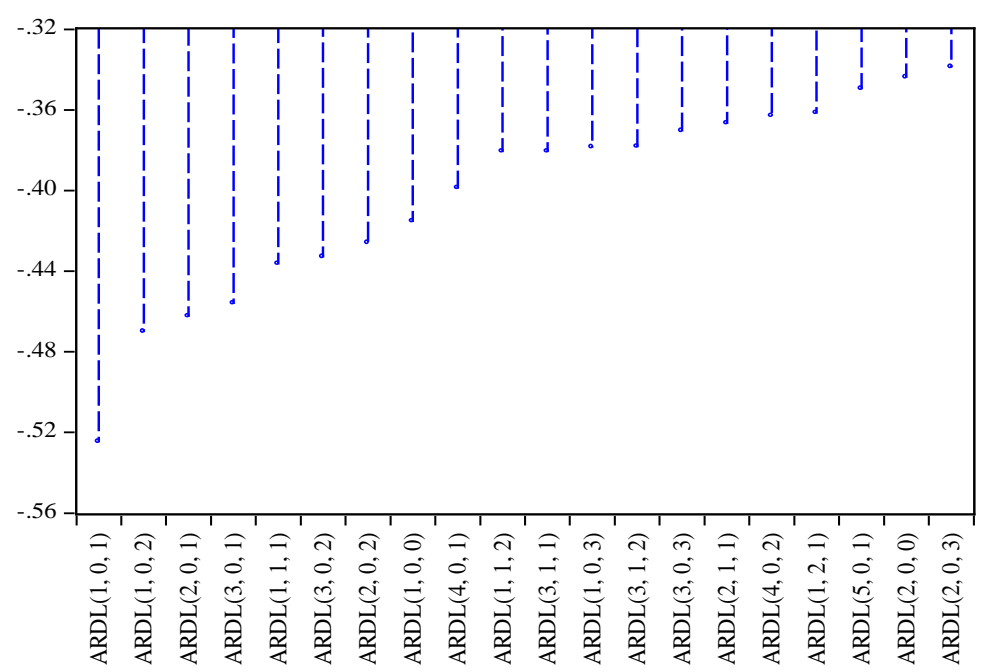

Figure 4. Lag Selection using the AIC, SIC and HQIC model selection techniques, 


$$
\delta_{j}=\frac{\sum_{i=1}^{p_{j}} \hat{\beta}_{j, i}}{1-\sum_{i=1}^{p} \lambda_{i}}
$$

The standard errors of $\delta_{j}$ 's were computed from the standard errors of $\lambda_{i}$ 's in Equation (1) above. Table 1 shows these long-run coefficients alongside the associated statistics.

\section{Cointegrating Relationships and Bounds Test for Existence of Conditional Level Long-Run Relationship}

As mentioned earlier, ARDL model is powerful in dealing with the setback encountered with the other traditional methods of cointegration by allowing the Gross Domestic Product (ngdp), Capital Expenditure (ce), Recurrent Expenditure (re) and the remaining static regressors, Crude Oil Price (cp) and Federal Government Retained Revenue (fgre) in the cointegrating relation to be entirely I(0), entirely I(1) or mutually cointegrated without conducting a unit root test such as an ADF or Phillips-Perron tests. Equation (2) is a conversion of Equation (1) into differences and replacing the $\delta_{j}$ 's from Equation (3) as:

$$
\begin{gathered}
E C_{t}=y_{t}-\alpha-\sum_{i=1}^{p} z_{j, i}^{\prime} \hat{\delta}_{j} \\
\hat{\phi}=1-\sum_{i=1}^{p} \hat{\lambda}_{i} \\
\lambda_{i}^{*}=\sum_{m=i+1}^{p} \hat{\lambda}_{m} \\
\beta_{j, i}^{*}=\sum_{m=i+1}^{p_{j}} \beta_{j, m}
\end{gathered}
$$

[17] developed a methodology for testing if the ARDL model in Equation (1) contains a conditional long-run relationship between the gross domestic product and the expenditure variables. We achieved this by converting the Equation (2) into the following model:

$$
\Delta y_{t}=-\sum_{i=1}^{p-1} \lambda_{i}^{*} \Delta y_{t-1}+\tau^{*} \Delta t_{t}+\psi^{*} \Delta D 2009_{t}+\sum_{j=1}^{k+2} \sum_{i=0}^{p_{j-1}} \Delta z_{j, t-i}^{\prime} \beta_{j, i}^{*}-\left(\rho y_{t-1}+c_{0}+c_{1} t+c_{2} D 2009+\sum_{j=1}^{k+2} z_{j, t-1}^{\prime} \theta_{j}\right)+\epsilon_{t}
$$

This method requires that none of the selected series is $\mathrm{I}(2)$ and involves the conduct of an asymptotic bounds test restricting the $\boldsymbol{\rho}$ and $\boldsymbol{\theta}_{j}$ 's to zero by conducting a joint test of hypothesis on these long-run coefficients. The null hypothesis is rejected if the calculated $F$-statistic is greater than the asymptotic critical value bounds for case where $c_{0} \neq 0$ and $c_{1} \neq 0$ provided in the table of critical values by [17]. Table 2 illustrates the result of the bound testing procedure.

Firstly, when $k=2$, Table 2 illustrates that the $F_{\text {cal }}=\frac{W}{k+2}=16.60$ lies outside the upper bounds of the critical bounds values for I(1) in Table CI(v) case V on page 301 of [17] when the intercept and trend are unrestricted, suggesting that the null hypothesis of no level Gross Domestic Product (ngdp) equation is rejected at 1 percent, 5 percent and 10 percent which is very high irrespective of whether the regressors are entirely $\mathrm{I}(0)$,

Table 1. Estimated Long-run coefficients, standard errors, $t$-statistics and $p$-values.

\begin{tabular}{ccccc}
\hline Long-run regressor & Coefficient & S.E & $\boldsymbol{t}$-Statistic & $\boldsymbol{p}$-Value \\
\hline $\operatorname{ngdp}_{(t-1)}$ & -0.8071 & 0.1236 & -6.5326 & $0.0000^{*}$ \\
$\mathrm{ce}_{(t-1)}$ & -0.0727 & 0.0451 & -1.6110 & 0.1164 \\
$\mathrm{re}_{(\mathrm{t}-1)}$ & -0.0571 & 0.1203 & -0.4750 & 0.6378 \\
\hline
\end{tabular}

*Statistically significant at 1 per cent level of significance. 
Table 2. Bounds test results on long-run coefficients.

\begin{tabular}{|c|c|c|c|}
\hline & & & \\
\hline Test Statistic & Value & Critical Bounds Value & \\
\hline \multirow{6}{*}{ F-statistic } & & $1 \%[\mathrm{I}(0), \mathrm{I}(1)], k=2$ & \\
\hline & $16.6^{*}$ & 6.34 & 7.52 \\
\hline & & $5 \%$ [I(0), I(1)], $k=2$ & \\
\hline & $16.6^{*}$ & 4.87 & 5.85 \\
\hline & & $10 \%[\mathrm{I}(0), \mathrm{I}(1)], k=2$ & \\
\hline & $16.6^{*}$ & 4.19 & 5.06 \\
\hline \multirow{6}{*}{ T-statistic } & & $1 \%[\mathrm{I}(0), \mathrm{I}(1)], k=2$ & \\
\hline & $-6.53^{*}$ & -3.96 & -4.53 \\
\hline & & $5 \%$ [I(0), I(1)], $k=2$ & \\
\hline & $-6.53^{* *}$ & -3.41 & -3.95 \\
\hline & & $10 \%[\mathrm{I}(0), \mathrm{I}(1)], k=2$ & \\
\hline & $-6.53^{* * *}$ & -3.13 & -3.93 \\
\hline
\end{tabular}

${ }^{*},{ }^{* *},{ }^{* * *}$ Test is significant at 1 percent, 5 percent and 10 percent level of significance respectively.

entirely I(1) or jointly cointegrated ${ }^{12}$. Secondly, we linked the result above with a $t$-test on the long-run coefficient of ngdp $_{\mathrm{t}_{-1}}$ with a value of -6.53 which when compared with critical values in Table CII(v) on pg. 304 of [17] for $t$-statistic indicates that at 1 percent, 5 percent and 10 percent levels of significance, the null hypothesis of no level Gross Domestic Product (ngdp) relationship is rejected regardless of the order of integration of the regressors. The results of the bounds test give rise to the estimation of the conditional long-run level relationship model in Equation (9) which determined the cointegrating equation $E \hat{C}_{t-1}$ (Table 3).

$$
n g d p_{t}=\underset{(0.6133)}{4.3421}+\underset{(0.0223)}{0.1047} t+\underset{(0.1095)}{0.1492} D 2009_{t}+\underset{(0.1126)}{0.8240} \text { fgre }+\underset{(0.0496)}{0.0214 c p_{t}}-\underset{(0.1493)}{0.1168 r e_{t}}-\underset{(0.0712)}{0.1113 c e_{t}}+E \hat{C}_{t}
$$

where $E \hat{C}_{t}$ is the error correction term with standard error expressed in the brackets. The standard errors of the static regressor, federal government retained revenue coefficient is much smaller than the coefficients signifying the significance of the variable at level. The following conditional unrestricted cointegrating form was derived employing the ARDL modeling procedure by [17] as illustrated in Table 3.

We observed a very weak contribution of economic theory in determining Nigerian domestic output model's long run and short-run properties because of its data dependencies. The conditional unrestricted level long-run level relationships and short-run dynamics show that 1 percent growth in oil price does not have a statistically significant effect on the Nigeria's domestic output during the review period. However, a small negative effect is an indication that the long-term rising oil price has had a diminishing effect on the overall economy over the years as a result of high net imports of oil per gross domestic product. Nigeria currently possesses dismal energy efficiency, persistently high dependence on oil revenue, and low self-sufficiency in fuel production. This has led to a great tendency to consume with little investments in the oil sector which has a multiplier effect on fiscal policy/government spending over the years. Again, increase in global oil prices have consistently led to increase in petrol, diesel and other "by-products" in spite of heavy subsidy incurred by the federal government ${ }^{13}$. As mentioned earlier this ensured the government continue to incur higher cost of importation of these "by-products". Consequently, oil subsidy partly contributed to the inverse relationship observed between oil prices and domestic output both in the long-run and short-run during the period under review. [4] emphasized that this may have severe consequences on firms relying heavily on energy from oil for their processes.

\footnotetext{
${ }^{12} \mathrm{~W}=66.4$ is the calculated value of the asymptotic Wald statistic [see [15]].

${ }^{13}$ This subsidy represents a substantially visible portion of government annual treasury budget. On the average, subsidy accounts for more than 30 percent and 4 percent of annual budget and gross domestic product respectively over the last decade. Some government policies have targeted its removal without success in order to reinvest its savings in empowerment programme such as infrastructural developments necessary to continually drive positive economic growth.
} 
Table 3. ARDL $(1,0,1)$ conditional unrestricted cointegrating form.

\begin{tabular}{ccccc}
\hline Regressor & Coefficient & S.E & $t$-Statistic & $p$-Value \\
\hline$\Delta \mathrm{ce}_{\mathrm{t}}$ & -0.0897 & 0.0536 & -1.6736 & 0.1034 \\
$\Delta \mathrm{re}_{\mathrm{t}}$ & -0.3582 & 0.1383 & -2.5899 & $0.0140^{* *}$ \\
$\Delta \mathrm{c}_{\mathrm{t}}$ & -0.0172 & 0.0402 & -0.4291 & 0.6706 \\
$\Delta$ fgre $_{\mathrm{t}}$ & 0.6640 & 0.1150 & 5.7731 & $0.0000^{*}$ \\
$\Delta \mathrm{D} 2009_{\mathrm{t}}$ & 0.1202 & 0.0920 & 1.3062 & 0.2003 \\
$\Delta$ trend $_{\mathrm{t}}$ & 0.0844 & 0.0221 & 3.8194 & $0.0005^{*}$ \\
EC(t-1) & -0.8059 & 0.1232 & -6.5397 & $0.0000^{*}$ \\
$R^{2}$ & 0.6154 & & \\
Adjusted $R^{2}$ & 0.5249 & & \\
AIC & $(0.9664)$ & & & \\
SC & $(0.5977)$ & & & \\
HQIC & $(0.8304)$ & & & \\
F-statistic & $6.8010^{*}$ & & &
\end{tabular}

*, ** statistically significant at 1 per cent and 5 per cent level of significant respectively. ${ }^{1} \mathrm{H}_{0}$ : the forecast errors are normally distributed, $(p$-values in parenthesis).

In the short run, the Nigerian domestic output model revealed that whilst recurrent expenditure was negative and statistically significant at 5 percent level of significance, capital expenditure's negative effect was negligible which is an indication of improved fiscal policy over the result of earlier study such as $[10]^{14}$. These negative effects are not surprising given that the country's over dependence on oil as the main source of government finances has led to obvious economic instability, high corruption rates, high and increasing risks of terrorist attacks in the North of the country and Niger Delta militants attack on oil installations over time. However, the model indicated that federal government retained revenue which comprise federation account levies, company income tax, custom and excise duties, value added tax (VAT) pool, allocation from excess crude account and independent sources such as government ministries/departments/agencies (MDAs, hereon) surpluses have a highly significant positive effect on the domestic output which was revealed in a coefficient close to unity (near-perfect) in the long-run. Specifically, a 10 percent growth in government retained revenue accounted for more than 8 percent and 6 percent increments in domestic output in the long-run and short-run respectively. This is in support of [12] who concluded that shocks on government retained revenue rather than government expenditure has the higher likelihood of forcing a positive response from domestic output growth in the long-run.

In contrast, [11] established that fiscal deficit which is an indication of higher government total expenditure relative to government retained earnings have a strong significant positive relationship with domestic output both in the long-run and short-run. A steadily increasing trend was observed in the values of federal government retained revenues over the review period. This rather high significant effect was not reflected in the government spending in driving the much required positive domestic output growth. In spite of the positive relationship between government retained revenues, expenditures have continued to influence the economy in the opposite direction. Higher level of corruption meant government spending on areas such as public debt servicing, economic services, social and community services, defense, internal securities and general administration have been consistently misappropriated by successive governments both at the federal and state levels over the years.

The coefficient of the cointegrating relation $E C_{\mathrm{t}-1}$ measures the speed of adjustment to disequilibrium caused by shocks on government spending in the model. A highly significant coefficient of -0.8059 with a rather small standard error (S.E) of 0.1232 implies that nearly 81 per cent of this disequilibrium is corrected within a year,

\footnotetext{
${ }^{14} \mathrm{An}$ annual 10 percent growth in recurrent expenditure is expected to lead to more than 3 percent significant dip in domestic output in the short-run.
} 
which is relatively high. This also implies that Nigerian Gross Domestic Product (ngdp) is extremely sensitive to shocks on government spending in the long-run. This model was checked for residual serial correlation and normality using the Bruesch-Godfrey Lagrange Multiplier (LM) Serial correlation test and Jarque-Bera test respectively. The LM was based on computed $F$-statistic $=1.7236(p$-value $=0.1946)$ which was compared with asymptotic $\chi^{2}=4.1814(p$-value $=0.1236)$ could not reject the null hypothesis of no residual serial correlations at all levels of significance. Furthermore, the Q-Statistic probabilities (Figure 5) indicate that there are no traces of partial correlation and autocorrelation in the error terms.

A VAR residual normality test based on a Jarque-Bera value of $0.0720(0.9646)$ indicates the residuals are multivariate normally distributed. These two model stability check procedure were done to ensure that our model on Nigeria domestic output can be used for forecasting purposes (Figure 6). Also, a VAR Stability condition checks on the inverse roots of the autoregressive characteristics polynomial showed that there exists one root which lies within the unit circle as required in the assumptions of an ARDL modeling (Figure 7). Furthermore, the model satisfies all the remaining necessary and sufficient assumptions under ARDL modeling.

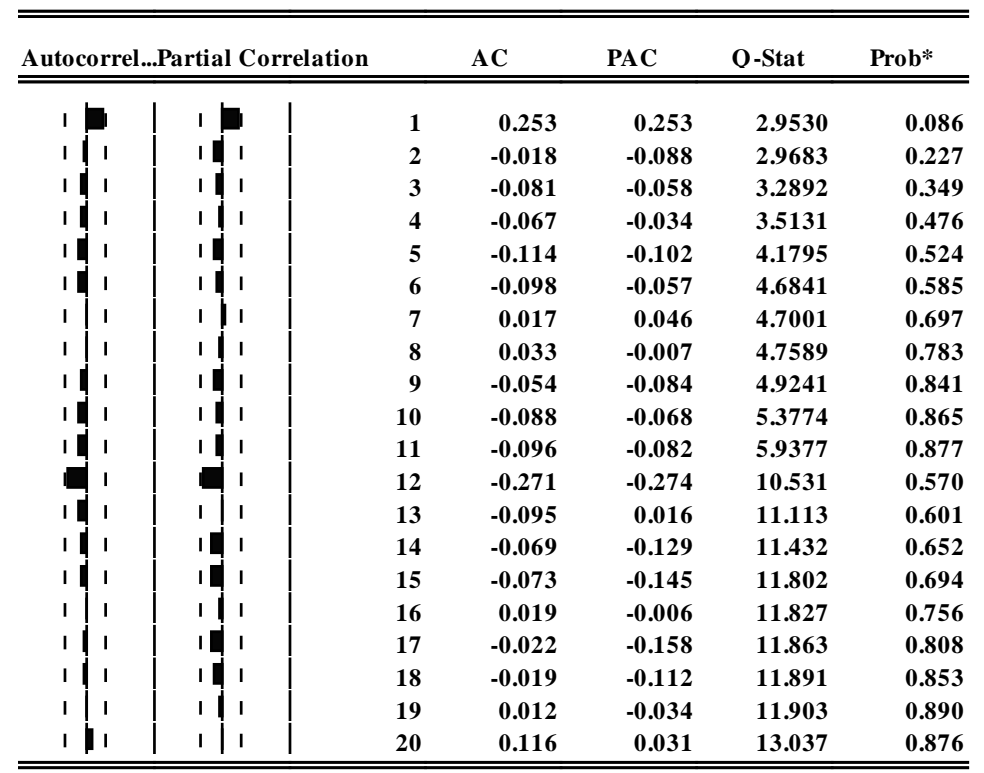

Figure 5. Autocorrelation and partial correlation plots with associated probabilities.

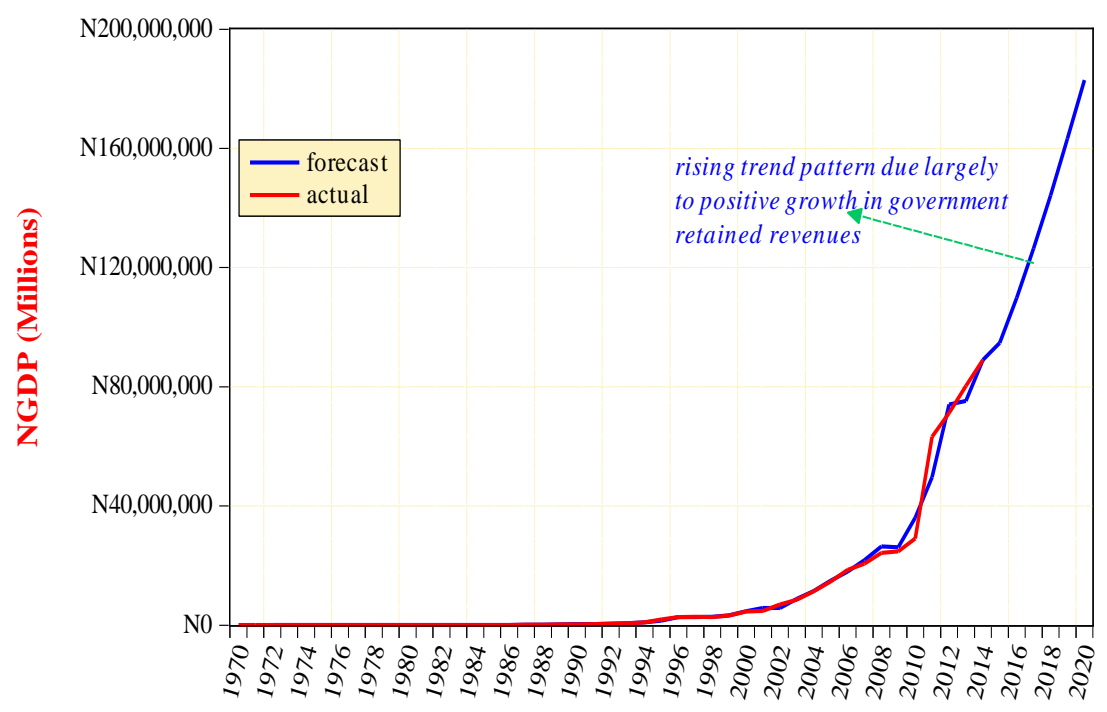

Figure 6. Nigerian GDP actual versus forecast values (period: 1970-2020). 
Inverse Roots of AR Characteristic Polynomial

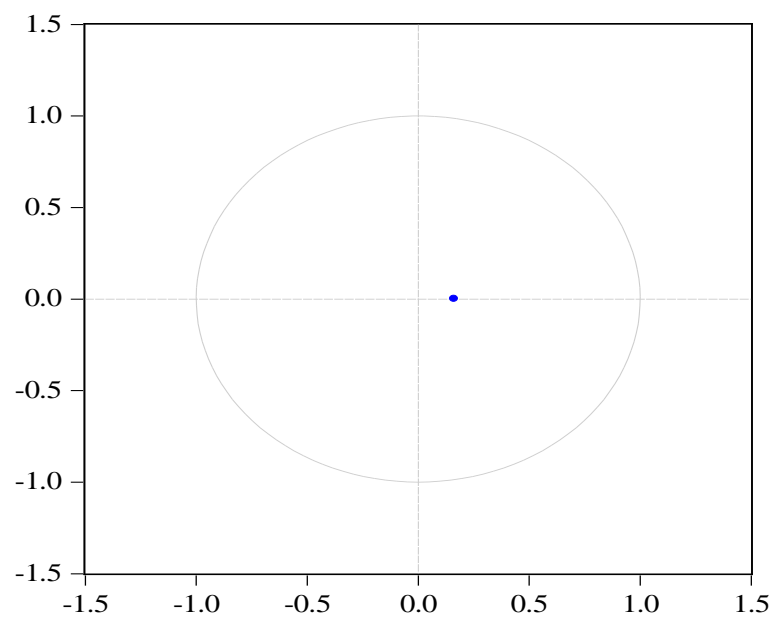

Figure 7. Inverse root of autoregressive characteristic polynomial.

The dynamic forecast figures from 2015 to 2020 (both inclusive) revealed a possible upward trend (an average of 12.8 per cent nominal growth rate over the six-year forecast period) in Nigeria Domestic Output in spite of persistent dwindling global oil prices (Figure 3). The forecast for 2015 indicated a 5.56 per cent growth over the 2014 actual value of over N89 trillion. This forecast is an indication of the resilient nature of the Nigerian economy. Also, this upward trend behavior implies that government retained revenue will continue to rise amidst oil crisis. Interestingly some sustainable sectors of the economy such as services, agriculture, entertainment (Nollywood) and manufacturing have recorded modest growth since the last three years.

Furthermore, liquidity in an economy depends significantly on government spending/expenditures which also drive major macroeconomic indicators such as inflation rates, unemployment rates, interest rates and exchange rate. [21] established a strong dependency of growth in domestic output on a deep financial development especially broad money supply (M2) relative to domestic output ${ }^{15}$. Hence, in order to ensure macroeconomic stability both in the long-run and short-run, the federal government has indicated its intention to increase efficiency in finances management to eliminate wasteful spending, introduction and full implementation of Treasury Single Account (TSA) ${ }^{16}$ to improve collection and remittance of revenues from MDAs and diversification of the economy to other viable sectors such as agriculture in order to increase the revenue base of the country. Improving revenue collection through diversification and remittance drive, elimination of leakages in government finances may make the economy resilient to oil shocks in the long-run.

\section{Conclusion}

It is without doubt that the discovery of oil has contributed immensely to government revenue over the years. But its contribution to national development is yet to be felt. This research work concludes that this is largely due to mismanagement of government finances at all levels as a consequence of incessant level of corruption, persistently high dependence on oil revenue and economic instability. Government budget/fiscal policy, which increases in accordance with increasing government revenue, has not translated into increase in domestic output during the period under review perhaps partly due to its small size relative to the overall economy. Therefore, in order to reverse the fortunes of the country and provide much needed resilience and capacity to cope with external shocks, improve macroeconomic policy effectiveness and support solid, durable inclusive growth in the

\footnotetext{
${ }^{15}$ According to their postulated model, a modest 6.79 percent, 7.83 percent, 7.73 percent, 7.21 percent, 7.48 percent and 8.15 percent real economic growth rates were forecasted for 2015, 2016, 2017, 2018, 2019 and 2020 respectively as a result of deep financial development in Nigeria.

${ }^{16}$ The Treasury Single Account (TSA) is a recent public finance reform agenda of the present government aimed at unifying all government accounts from MDAs in a consolidated account in order to minimize the cost of government borrowing (interest rates on loans) and maximize the opportunity cost of cash resources. Also it ensures the availability of every government cash for carrying out government spending efficiently.
} 
presence of long-term declining crude oil prices, the government at both the federal and state levels must improve revenue collection and remittance drive (by diversification) and eliminate leakages in government finances. This will reverse the downward trend in the proportion of both government's retained revenue and spending relative to national domestic output, which will contribute to the economy's resilience to oil price shocks in the nearest future.

\section{References}

[1] Omoniyi, L.G., Olawale, A.N. and Matanmi, O.G. (2015) A Conditional Restricted Equilibrium Correction Model on Nigerian Stock Exchange All-Share Index and Macroeconomic Indicators with 2008 Global Financial Crisis Effects: A Univariate Framework Approach. American Journal of Mathematics and Statistics, 5, 150-162.

[2] Price Water Cooper Report (2013) Shale Oil: The Next Energy Revolution. Retrieved November 28, 2015. www.pwc.com/gx/en/oil-gas-energy/publication/pdfs/pwc-shale-oil.pdf

[3] Schmidt, T. and Zimmermann, T. (2005) Effects of Oil Price Shocks on German Business Cycle. Rhine-Westphalia Institute for Economics Research RWI Discussion Paper No 31.

[4] Blanchard, O.J. and Gali, J. (2007) The Macroeconomic Effects of Oil Price Shocks: Why the 2000's So Different from the 1970s. NIBER Working Paper 13368.

[5] Olomola, P. (2006) Oil Price Shocks and Aggregate Economic Activity in Nigeria. African Economic and Business Review, 4, 40-45.

[6] Oriakhi, D.E. and Osaze, I.D. (2013) Oil Price Volatility and Its Consequences on the Growth of the Nigerian Economy: An Examination (1970-2010). Asian Economic and Financial Review, 3, 683-702.

[7] Wakeford, J.J. (2006) The Impact of Oil Price Shocks on the South African Macroeconomy: History and Prospects. South African Reserve Bank Conference 2006, Johannesbourg, 2006.

[8] Adissei, J. and Georg, P. (2007) Oil Price Shocks, Monetary Policy and Aggregate Demand in Ghana. Reihe Okonomie Economics Series, No. 212.

[9] Amara, B. (2012) The Relationship of Oil Prices and Economic Growth in Tunisia: A Vector Error Correction Model Analysis. Romanian Economic Journal, 15, 3-22.

[10] Akanni, K.A. and Osinowo, O.H. (2013) Effect of Fiscal Instability on Economic Growth in Nigeria. Advances in Economics and Business, 1, 124-133.

[11] Nathan, P. (2012) The Impact of Fiscal Policy on the Nigerian Economy. International Review of Social Sciences and Humanities, 4, 142-150.

[12] Yakubu, M., Asare, B.K. and Gulumbe, S.U. (2013) Effects of Monetary-Fiscal Policies/Interaction on Oil Price and Output Growth in Nigeria. CBN Journal of Applied Statistics, 4, 55-74.

[13] Iyeli, I.I., Uda, E.B. and Akpan, E. (2012) The Relative Effectiveness of Monetary and Fiscal Policies in Economic Stabilization in a Developing Economy: An Empirical Evidence. Nigeria Annals of Humanities and Development Studies, 3, 87-138.

[14] Alege, P.O. and Izedonmi, I.O.F. (2008) The Impact of Monetary and Fiscal Policy on the Real Gross Domestic Product of Nigeria, 1970-2003. The West African Financial and Economic Review (WAFER), 2, 32-58.

[15] Ogbole, O.F., Amadi, S.N. and Essi, I. (2011) Fiscal Policy and Economic Growth in Nigeria: A Granger Causality Analysis. American Journal of Social and Management Sciences, 2, 356-359. http://dx.doi.org/10.5251/ajsms.2011.2.4.356.359

[16] Pesaran, M.H. and Shin, Y. (1999) An Autoregressive Distributed Lag Modelling Approach to Cointegration Analysis. In: Strom, S., Ed., Chapter 11 in Econometrics and Economic Theory in the 20th Century the Ragnar Frisch Centennial Symposium, Cambridge University Press, Cambridge, 371-413.

[17] Pesaran, M.H., Yongcheol, S. and Richard, J.S. (2001) Bounds Testing Approaches to the Analysis of Level Relationships. Journal of Applied Economics, 16, 289-326. http://dx.doi.org/10.1002/jae.616

[18] Engle, R.F. and Granger, C.W.J. (1987) Cointegration and Error Correction Representation, Estimation and Testing. Econometrica, 55, 251-276. http://dx.doi.org/10.2307/1913236

[19] Johansen, S. (1988) Statistical Analysis of Cointegration Vectors. Journal of Economic Dynamics and Control, 12, 231-254. http://dx.doi.org/10.1016/0165-1889(88)90041-3

[20] Omoniyi, L.G. and Olawale, A.N. (2015) An Application of ARDL Bounds Testing Procedure to the Estimation of Level Relationship between Exchange Rate, Crude Oil Price and Inflation Rate in Nigeria. International Journal of Statistics and Applications, 5, 81-90. 
[21] Omoniyi, L.G., Olawale, A.N., Matanmi, O.G. and Taofik, A.O. (2015) Forecasting Real Economic Growth from Relative Depth of Financial Development in Nigeria: A Multivariate Framework Approach. 39th Nigerian Statistical Association 2015 Annual Conference, Oshogbo, 2015. 